\title{
multicenter double blind study of THS-201 (halopredone acetate) in rheumatoid arthritis
}

慢性関節リウマチに対する THS-201 (halopredone acetate) の

多施設二重盲検比較試験

\section{drug evaluation}

THS-201 研究会

世話人 : 塩川優一*1), 七川歓次*2)

水島 裕 ${ }^{* 3)}$, 景山孝正*4)

広畑和志 ${ }^{* 5)}$, 山本 真*6)

青木虎吉*7)，菅原幸子*8)

コントローラー：岩崎由雄 ${ }^{9)}$

慢性関節りウマチ (RA) に刘するステロイド関節注入 療法は, Hollander ら ${ }^{1)}$ によ開始されて以来30年以上 経過するが, 現在でも RA に対する有効な治療法とし て広く用いられている.この治療法の目的は, 強力な抗 炎症作用を有する反面, 全身的な副作用も強いステロイ ド剂を炎症局所に直接注入することにより，目的とする 部位のみにその抗炎症効果を期待するものである.

しかし, 問題点としては, 効果の持続が短かいこと, 局所の副作用のあることであるが，また一方，従来のス テロイド関節注入剂は，局所投与にもかかわらず，注入 後かなり速やかに全身循環に入るので，その効力は局所 作用之同時に全身的作用にもよることから，経口的に投 与したときと同じような全身的副作用がある ${ }^{2 \sim 3)}$.

今回, 筆者らが検討したTHS-201(一般名 halopredone acetate) は, 動物実験に括いて局所貯留性が高いことに より強力な局所の抗炎症作用を有し, 効果の持続がなが く，しかも全身作用がきわめて少ないといら特徵を有す ることが確認されている4). 図1にその構造式を示す。

前回，筆者らの実施した open trial において，RA の膝関節に対しては本剂 $25 \mathrm{mg}$ で十分有効であること が認められた5)ことにより, 今回，さらに本剂の有用性 を客観的に確認する目的で, 酢酸メチルプレドニゾロン を対照薬とした二重盲検比較試験を実施し，併せて両薬 剤の全身影響をも検討したので，その結果を報告する。 実施施設は表 1 に示した16施設であり，本試験は昭和58 年 3 月より 59 年 2 月までの 1 年間にわたり実施された。

\section{試験方法}

(1) 対象患者

アメリカ・リウマチ協会（ARA）の診断基準による

*1) 順天堂大学膠原病内科学教室

*2）滋賀医科大学整形外科学教室

*3) 聖マリアンナ医科大学第一内科学教室

*4) 国立相模原病院整形外科

*5) 神戸大学医学部整形外科学教室

*6) 北里大学医学部整形外科学教室

*7) 順天堂大学医学部整形外科学教室

*8) 東京女子医科大学第二病院整形外科

*9) 東京大学分院薬剤科

代表世話人：塩川優一，諭文執筆者：水島 裕

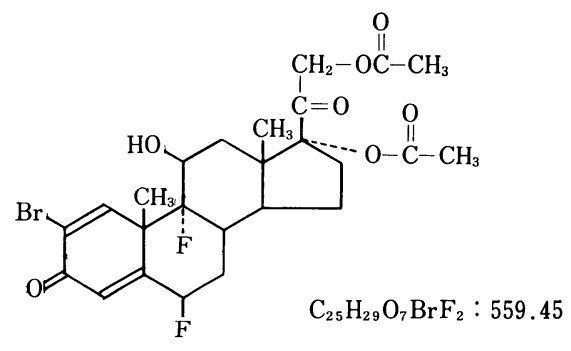

THS-201

化学名 : (-)-17 $\alpha, 21$-diacetoxy-2bromo-6 $\beta, 9 \alpha$-difluoro$11 \beta$-hydroxy-1, 4-pregnadiene-3, 20-dione

一般名： halopledone acetate

図 1 THS-201 の構造式

classical ないし definite RA と診断され, 膝関節への ステロイド注入療法が適応となる患者を対象とし, 以下 の項目に該当するものは対象から除外した。

(1) 年齢が16歳未満, 75歳以上のもの

(2) 重い合併症を有するもの

(3) 妊娠女性および試験期間中に妊娠の可能性のある もの

(4) 関節に感染症のあるもの

(5) 関節の不安定なもの

(6) その他, 担当医が試験対象として不適当と思われ るもの

なお，今回の試験に参加することについては，前もっ て試験の内容を説明したら党で同意を得た患者を対象と し, 同意取得の年月日を調查表に記入した。

(2) 試験力法

(1) 試験薬剂

試験薬剂 THS-201 (THS) は, 1 バィアル中 $25 \mathrm{mg}$ $(1 \mathrm{~m} l)$ を含有する水性懸濁注射剂であり，対照薬剤は， 現在，ステロイド関節注入剂としてもっとも広く使用さ れている薬剤の一つであり, しかも市販されている同効 品のなかでは外観が THS とさわめて類似している点 より, 酢酸メチルプレドニゾロン (MPA)を選定し, そ の 1 バィアル中 $40 \mathrm{mg}(1 \mathrm{ml})$ を含有する製剤を使用し た，THS は大鵬薬品工業より，MPA は日本アップジ ョンより提供を受けた。試験薬剤の外観識別不能性の保 
表 1 試験実施施設（順不同）

$\begin{array}{ll}\text { 国立鳴子病院 } & \text { 整形外科 } \\ \text { 東京女子医科大学第二病院 } & \text { 整形外科 } \\ \text { 立川共済病院 } & \text { 整形外科 } \\ \text { 川崎市立井田病院 } & \text { 整形外科 } \\ \text { 聖マリアンナ医科大学 } & \text { 第一内科 } \\ \text { 北里大学 } & \text { 整形外科 } \\ \text { 愛知医科大学 } & \text { 整形外科 } \\ \text { 名古屋大学 } & \text { 整形外科 } \\ \text { 国立名古屋病院 } & \text { 整形外科 } \\ \text { 滋賀医科大学 } & \text { 整形外科 } \\ \text { 国立大阪南病院 } & \text { 整形外科 } \\ \text { 松下病院 } & \text { 整形外科 } \\ \text { 近畿大学 } & \text { 整形外科 } \\ \text { 神戸大学 } & \text { 整形外科 } \\ \text { 山口大学 } & \text { 整形外科 } \\ \text { 熊本大学 } & \text { 整形外科 }\end{array}$

証, 薬剤の無作為割付けならびに割付け表の保管はコン トローラーが行い, また, 緊急コードを作成し，代表世 話人の塩川が，これを保管した。 コントローラーが任意 に抜き取った試験薬剤の製剤学的試験は, 星薬科大学薬 剤学教室（永井恒司教授）に依頼して行われ，その適合 性が確認された.

(2) 投与方法

試験薬剂は 1 回 $1 \mathrm{~m} l$ を膝関節腔内に投与し，観察期 間は12週間とした．投与間隔は原則として 4 週間隔（3 回投与）とするが，患者の状態に応じて行うこととし た。な括，投与時に対象関節に対し，排液の実施の有無 を記載し, 穿刺排液を行った場合には, その量を調查用 紙に記録した。

(3) 併用療法

試験期間中は, 他のステロイド剂 (経口剂, 外用剂)な どの併用は行わないこととした，金剤または D-ペニシ ラミンについては, 維持量に達しているものは, その量 を変更せずに投与しても差し支えないが，試験期間中に 新たにはじめないこととし，なた，非ステロイド性鎮痛・ 抗炎症剤（外用剂，坐剤なども含む）は，試験開始前よ り投与している薬剤を変更せずに，試験期間中もそのま ま継続投与することとした。

その他の薬物療法扣よび理学療法についても, 試験開 始前より行っているものは, その内容を変更せずにその まま継続し，本試験期間中に新たにはじめないこととし た.

なお，併用療法を行った場合は，薬剂名，1日投与量 などを必ず調査用紙に記載することとした。

(4) 評価項目および評価方法

i 対象関節の重症度 : 試験開始時に対象関節の重症 度を高度, 中等度, 軽度の 3 段階で評価した。なお，膝
表 2 症例構成

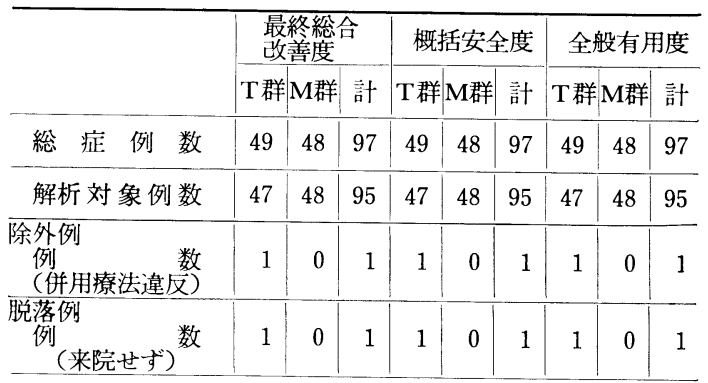

T 群 : THS-201 25mg/回

M群：酢酸メチルプレドニゾロン $40 \mathrm{mg} /$ 回

関節の炎症症状のために仕事または日常生活の動作が困 難なものを高度とし, 中等度, 軽度はこれに準じて判定 した.

ii 臨床症状：下記の項目を原則として 投与開始日よ り試験終了時まで，関節内注射の有無にかかわらずつぎ の要領で評価した，a . 疼痛症状（自発痛, 圧痛, 他動 運動痛), 関節腫脹, ADL の障害 (歩行, 正座, 乙ゃ がも動作, 階段昇降) は, 高度, 中等度, 軽度, なし, の 4 段階で評価した。 b . 運動範囲角度は, 屈曲角度お よび伸展角度を記録した。

iii 診察時の総合改善度：投与後の各評日に，その時 点での注射局所症状の総合改善度を試験開始時と比較し て, 著明改善, 中等度改善, 軽度改善, 不変, 軽度悪 化，悪化，著明に悪化，の 7 段階で評価した。

iv 全身のリウマチ症状のチェック：薬剤投与前後 に, 朝のこわばりの持続時間, 握力, 血沈および活動性 関節数などの全身状態を調査した。

$\mathrm{v}$ 副作用：副作用と思われる 症状が発現した場合に は, その症状, 発現日, 程度, 持続期間, 処置, 薬剤之 の因果関係（あり，多分あり，どちらともいえない，多 分なしなし）を記録した。

vi 臨床検査: 一般血液検査（赤血球数, 白血球数, 白血球分類, 血色素量, 血小板数), 血液生化学検查 (GOT, GPT, Al-P, BUN, クレアチニン, $\mathrm{Na}, \mathrm{K}$, $\mathrm{Cl}$ ), 尿検査（蛋白，糖，ウ口ビリノーゲン，沈渣）を 必須検查項目とし，原則として，試験開始前より4 週ご とに試験終了時まで実施した。臨休検査の特別な異常値 を認めた場合には, 試験終了後も追跡調查して, 結果を 調査用紙に記録することとした。

vii 総合評価：最終総合改善度（注射局所症状の） は, 試験終了時に試験薬剂の局所の効果の程度を総合し て試験開始時と比較し, 著明改善, 中等度改善, 軽度改 善, 不変, 軽度悪化, 悪化, 著明に悪化, の 7 段階で評 価した。概括安全度については, 試験期間中の副作用, 臨床検査值の異常の種類, 程度, 推移などを考慮して, 安全, 核安全, 安全とはいい切れない, 安全性に問題 
表 3 患者の背景

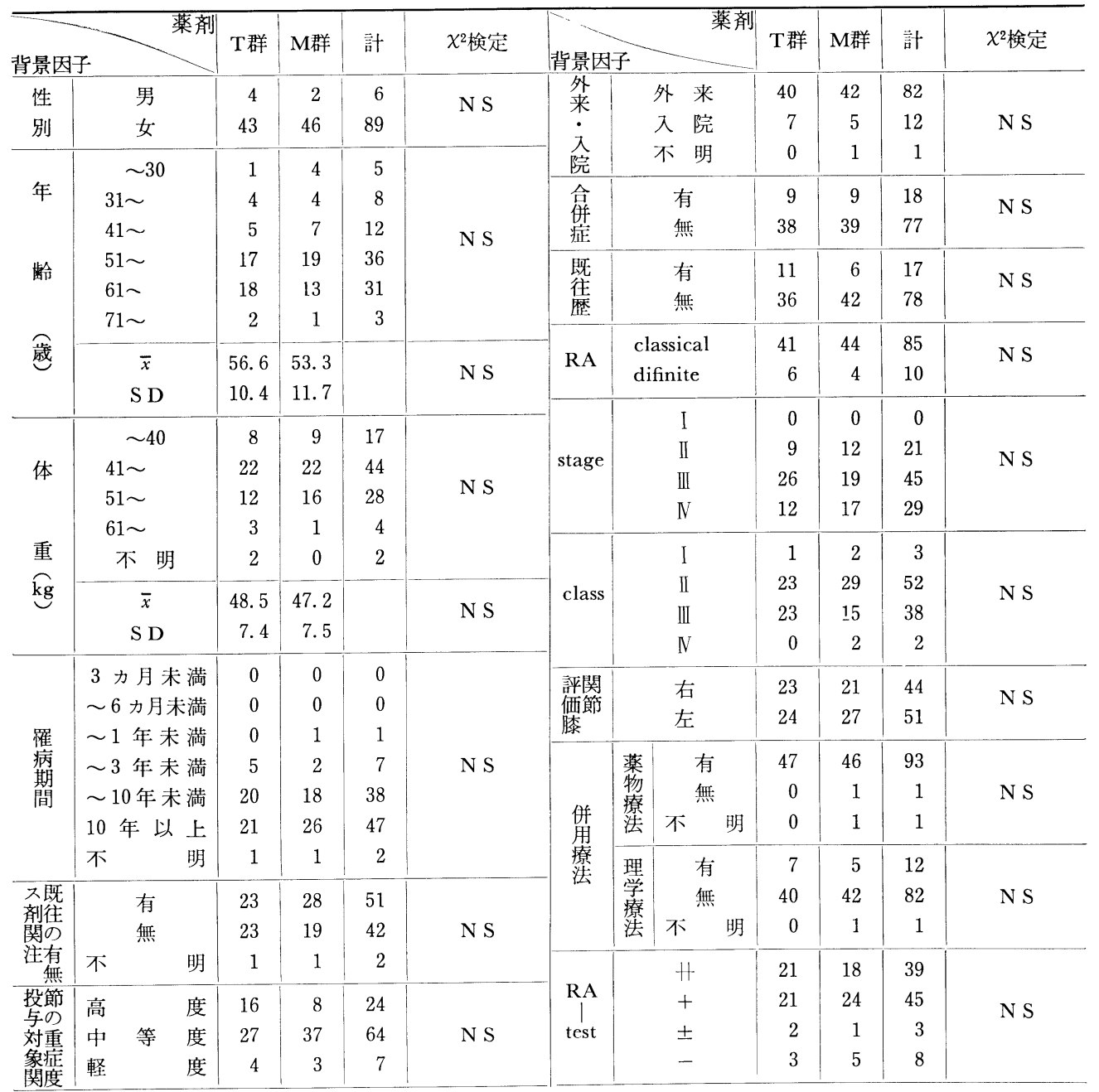

NS: not significant

がある, 安全でない, の 5 段階で判定した。ささらに, 最 終総合改善度, 効果の持続性, 概括安全度なぞを総合的 に勘案して, 試験薬剤の全般有用度を, 極めて有用, か なり有用, やや有用, どちらともい方ない, やや好まし くない，かなり好ましくない，極めて好ましくない，の 7 段階で評価した.

viii 試験の中止・脱落 : 症状悪化, 副作用, その他 により試験続行が不可能な場合は, その時点で中止する こととし, 中止した場合は規定の観察, 評価を行い, 中 止の理由を調查用紙に記載した。試験薬剂の投与を開始 した患者の調査用紙は，すべて回収し，データの不備な 点は主治医に連絡して確認した後, key code 開封前に コントローラーおよび世話人が各症例を検討して脱落, 中止例の扱いを協議決定した.

ix 解析方法 : 試験成績の解析火は, $\chi^{2}$ 検定, MannWhitney $の \mathrm{U}$ 検定, Student $の \mathrm{t}$ 検定, Wilcoxon I 標
本検定を用いた。

$\mathrm{x}$ 全身影響試験：薬剤の全身に対する影響をみる目 的で，全身影響試験用として別個にコントローラーが無 作為割付けした薬剤を, 患者の膝関節に 1 回投与し, 投 与前に 2 回（投与前 14 日以内）, 投与後 24 時間目, 72 時間目（3 日目），168時間目（7 日目）飞，血液検查と して, 血清コルチゾール值, 血清総蛋白量, 末梢血好酸 球数, 尿検查として, 1 日尿量, 尿中 17-OHCS, Na, $\mathrm{K}, \mathrm{Cl}$ の各検查を実施可能な施設で行った.

\section{試験成績}

\section{(1) 対象症例}

key code 開封前に, 世話人会にて試験薬剤を投与さ れた97例についての症例検討会を実施し，その結果，1 例が投与開始以後来院せず， 1 例が試験期間中に他のス テロイド関節注入剂を, 被験部位に投与したという理由 
a. 最終総合改善度

表 4 総合評価

\begin{tabular}{|c|c|c|c|c|c|c|c|c|c|c|c|c|c|}
\hline \multirow{2}{*}{$\begin{array}{l}\text { 薬 } \\
\text { 郕 }\end{array}$} & \multicolumn{2}{|r|}{ 最 } & 総 & 合 & \multicolumn{2}{|l|}{ 改 } & \multicolumn{2}{|l|}{ 度: } & \multirow{2}{*}{ 計 } & \multicolumn{2}{|c|}{ 有効率(\%) } & \multirow{2}{*}{$x^{2}$ 検定 } & \multirow{2}{*}{ U検定 } \\
\hline & 著明改善 & $\begin{array}{l}\text { 中 } \\
\text { 等 度 } \\
\text { 改 }\end{array}$ & 軽度改善 & 不 変 & 軽度悪化| & 悪 & 化 & 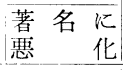 & & $\begin{array}{l}\text { 中 等 度 } \\
\text { 改善以」 }\end{array}$ & $\begin{array}{c}\text { 堅度改善 } \\
\text { 上 }\end{array}$ & & \\
\hline $\mathrm{T}$ & $\begin{array}{c}7 \\
(14.9 \%)\end{array}$ & $\begin{array}{c}21 \\
(44.7 \%\end{array}$ & $(25.5 \%)$ & $(12.8 \%)$ & $(2.1 \%)$ & & 0 & 0 & 47 & 59.6 & 85.1 & & \\
\hline M & $\begin{array}{c}11 \\
(22.9 \%)\end{array}$ & $\begin{array}{c}19 \\
(39.6 \%)\end{array}$ & $(25.0 \%)$ & $\begin{array}{c}5 \\
(10.4 \%)\end{array}$ & $(2.1 \%)$ & & 0 & 0 & 48 & 62.5 & 87.5 & & \\
\hline
\end{tabular}

b. 概括安全度

*中等度改善以上と軽度改善以下について検定

\begin{tabular}{|c|c|c|c|c|c|c|c|c|c|}
\hline \multirow{2}{*}{$\begin{array}{l}\text { 薬 } \\
\text { 郕 }\end{array}$} & \multicolumn{5}{|c|}{ 概 括 安 全 度 } & \multirow{2}{*}{ 計 } & \multirow{2}{*}{$\begin{array}{c}\text { 副 作 用 } \\
\text { 発 現 率 } \\
(\%)\end{array}$} & \multirow{2}{*}{${ }^{*} x^{2}$ 検定 } & \multirow{2}{*}{ U検定 } \\
\hline & 安 全 & ほぼ安全 & $\mid \begin{array}{l}\text { 安全とはいい } \\
\text { きされい }\end{array}$ & $\begin{array}{l}\text { 安全性題がある } \\
\text { 岁 }\end{array}$ & 安全でない & & & & \\
\hline $\mathrm{T}$ & $\begin{array}{c}43 \\
(91.5 \%)\end{array}$ & $(2.1 \%)$ & 0 & $\begin{array}{c}2 \\
(4.3 \%)\end{array}$ & $(2.1 \%)$ & 47 & 8.5 & \multirow{2}{*}{ N S } & \multirow{2}{*}{$\mathrm{NS}$} \\
\hline M & $\begin{array}{c}46 \\
(95.8 \%)\end{array}$ & $\begin{array}{c}1 \\
(2.1 \%)\end{array}$ & 0 & $(2.1 \%)$ & () & 48 & 4.2 & & \\
\hline
\end{tabular}

c. 全般有用度

*副作用の有無について検定

\begin{tabular}{|c|c|c|c|c|c|c|c|c|c|c|c|c|}
\hline \multirow{2}{*}{$\begin{array}{l}\text { 薬 } \\
\text { 剤 }\end{array}$} & & & 全 & 般 & 用 & 度 & & \multirow{2}{*}{ 計 } & \multicolumn{2}{|c|}{ 有用率 $(\%)$} & \multirow{2}{*}{${ }^{*} x^{2}$ 検定 } & \multirow{2}{*}{ U検定 } \\
\hline & $\begin{array}{ll}\text { 極 め } \\
\text { 有 } \\
\end{array}$ & $\begin{array}{lll}\text { C用|有 } & & \text { 用 }\end{array}$ & やや有用 $\mid$ & $\begin{array}{l}\text { どちらとも } \\
\text { いえない }\end{array}$ & $\begin{array}{l}\text { やや好ま } \\
\text { Lくない }\end{array}$ & $\mid \begin{array}{l}\text { かなり好ま } \\
\text { しくない }\end{array}$ & $\begin{array}{l}\text { 極めて好ま } \\
\text { しくない }\end{array}$ & & $\begin{array}{l}\text { かな } \\
\text { 有用以上 }\end{array}$ & $\begin{array}{l}\text { やや } \\
\text { 有用以上 }\end{array}$ & & \\
\hline $\mathrm{T}$ & $\begin{array}{c}10 \\
(21.3 \%)\end{array}$ & $\left(\begin{array}{c}19 \\
(40.4 \%)\end{array}\right.$ & $\begin{array}{c}11 \\
(23.4 \%)\end{array}$ & $\begin{array}{c}5 \\
(10.6 \%)\end{array}$ & $(2.1 \%)$ & 0 & $(2.1 \%)$ & 47 & 61.7 & 85.1 & \multirow{2}{*}{$\mathrm{N} \mathrm{S}$} & \multirow{2}{*}{ N S } \\
\hline M & $\begin{array}{c}14 \\
(29.2 \%)\end{array}$ & $(39.6 \%)$ & $\left(\begin{array}{c}8 \\
(16.7 \%)\end{array}\right.$ & $\begin{array}{c}5 \\
(10.4 \%)\end{array}$ & $\left(\begin{array}{c}2 \\
(4.2 \%)\end{array}\right.$ & 0 & 0 & 48 & 68.8 & 85.4 & & \\
\hline
\end{tabular}

*かなり有用以上とやや有用以下について検定 NS : not significant

で解析不採用とし，95例 (THS 群47例, MPA 群48例) が，最終総合改善度，概括安全度，全般有用度の解析対 象例として採用された（表 2 ）。

（2）患者の背景

解析対象 95 例について, THS 群47例, MPA群48例の 背景因子を検討したが，性，年齢，体重，入院・外来， RA 診断上の区分, 病期, 機能障害, 罹病期間, 既往治 療および投与対象関節の重症度などのいずれにも問題と なる偏りは認められなかった（表 3 ).

\section{(3) 最終総合改善度}

試験終了時に試験薬剤の投与局所に対する効果の程度 を総合して, 試験開始時と比較した最終総合改善度にお いては, 中等度改善以上で THS 群 $59.6 \%$, MPA 群 $62.5 \%$, 軽度改善以上で THS 群 $85.1 \%$, MPA 群 87.5 \%と兩群間に有意差は認められなかった（表 $4 \mathrm{a}$ )。

\section{(4) 症状別改善度}

試験薬剂投与局所の自発痛, 圧痛, 他動運動痛の各疼 痛症状，および関節腫脤，関節穿刺排液量，ADL の障 害（歩行, 正座, しゃがむ動作, 階段昇降) の各項目の 変動を検討したが，両群ともすべての項目に打いても，

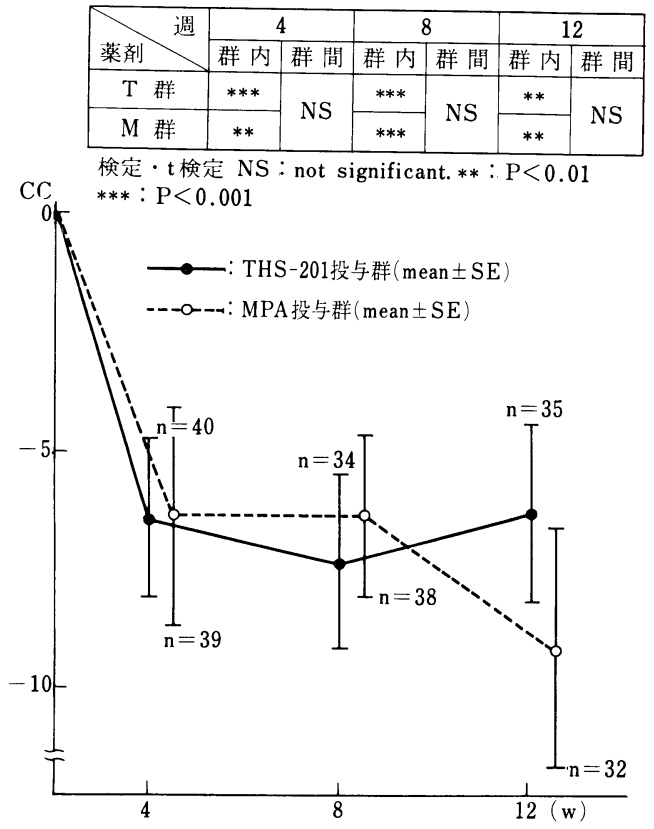

図 2 穿刺廃液量の推移 


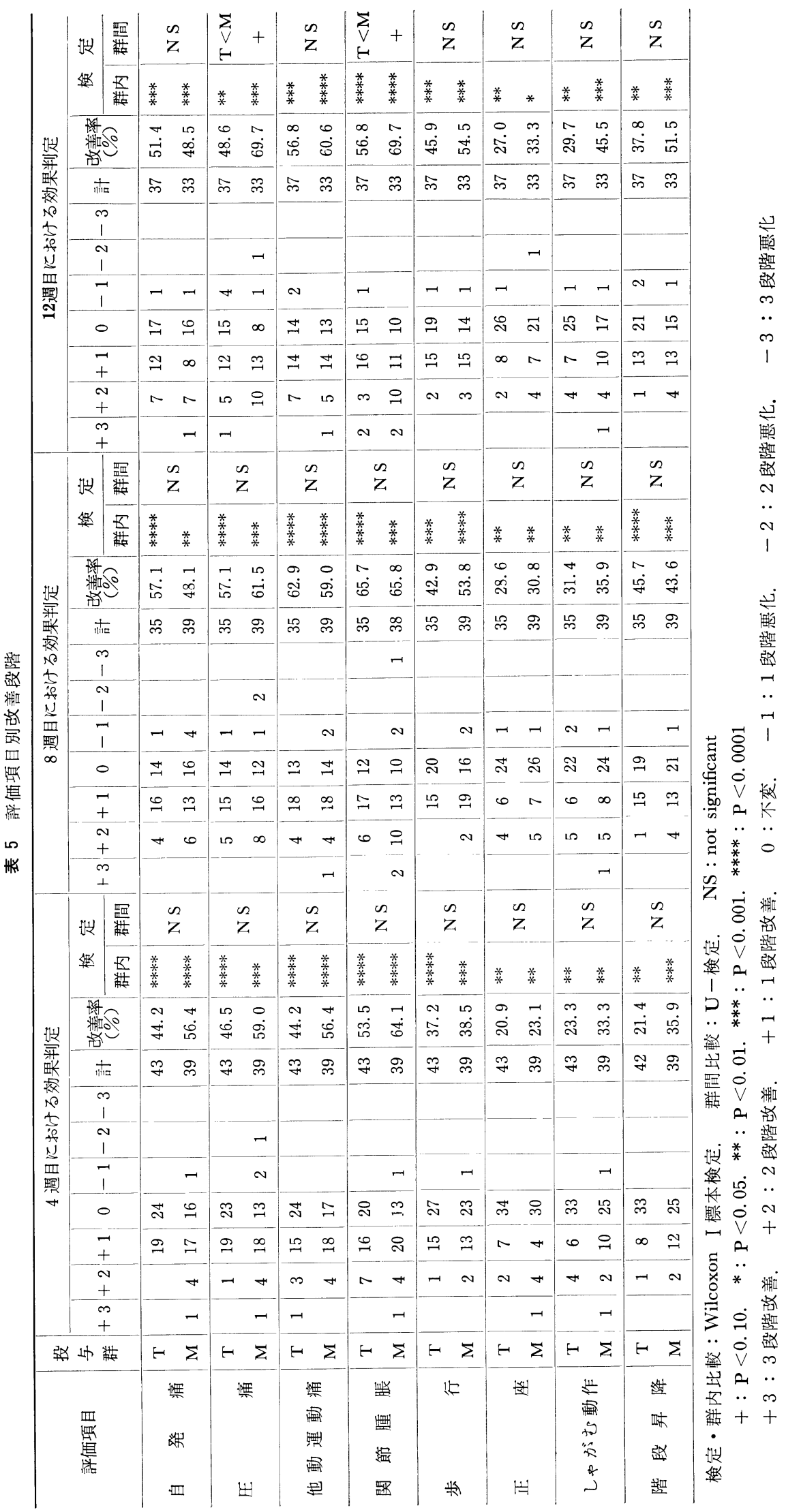


表 6 総合改善度の推移

\begin{tabular}{|c|c|c|c|c|c|c|c|c|c|c|}
\hline \multirow{2}{*}{$\begin{array}{l}\text { 評価 } \\
\text { 時期 }\end{array}$} & \multirow{2}{*}{$\begin{array}{l}\text { 薬 } \\
\text { 斉 }\end{array}$} & \multicolumn{6}{|c|}{ 総合改善度 } & \multicolumn{2}{|c|}{ 改善率 } & \multirow{2}{*}{ U検定 } \\
\hline & & $\begin{array}{l}\text { 著明 } \\
\text { 改善 }\end{array}$ & $\begin{array}{l}\text { 中等是 } \\
\text { 改 }\end{array}$ & 筀 & 悹不 & & $\begin{array}{l}\text { 度 }^{\text {化 }} \\
\end{array}$ & & $\begin{array}{c}\text { (俥圣度改 } \\
\text { 普以上) }\end{array}$ & \\
\hline \multirow{2}{*}{4 週後 } & $\mathrm{T}$ & 4 & 9 & 16 & 13 & 1 & & 43 & 67.4 & \multirow{2}{*}{ N S } \\
\hline & $\mathbf{M}$ & 6 & 14 & 8 & 9 & 2 & & 39 & 71.8 & \\
\hline \multirow{2}{*}{8 週後 } & $\mathrm{T}$ & 3 & 14 & 11 & 5 & 2 & 3 & 35 & 80.0 & \multirow{2}{*}{ N S } \\
\hline & $\mathbf{M}$ & 6 & 17 & 7 & 7 & 2 & & 39 & 76.9 & \\
\hline \multirow{2}{*}{ 12週後 } & $\mathrm{T}$ & 4 & 14 & 8 & 9 & 2 & 37 & 37 & 70.3 & \multirow{2}{*}{ N S } \\
\hline & $\mathbf{M}$ & 15 & 14 & 8 & 4 & 2 & & 33 & 81.8 & \\
\hline
\end{tabular}

NS : not significant

投与開始時の症状程度とくらべ，投与 4 週目， 8 週目， および12週目のいずれの評価時期においても有意な改善 を示した．また，両群間の改善程度の比較においては, 圧痛および関節腫脹の評価項目で12週後に MPA 群が THS 群にすぐれる改善がみられたが, 他の項目では両 群間に有意差は認められなかった（図 2 , 表 5 ).

(5) 概括安全度

副作用 発現率は, THS 群 $8.5 \%$ (4/47), MPA 群 4. $2 \%$ (2/48) であり, 両群間に有意差は認められなか った，副作用の内訳は，THS 群汇局所の腫脹，局所の 疼痛, 全身の浮腫が各 1 例, また, そのほかに THS 投 与15日目に被験部位の膝関節には変化はなかったが，他 の関節炎症が増悪したといらことで, 主治医により本剂 の副作用であると判定された症例が 1 例あった.

一方, MPA 群では, 臨床検査上 2 例飞副作用が認め られ，1例は MPA 投与後肝機能検查值の悪化, 白血 球数の增加および血小板数の一時的な著減がみられ, 他 の 1 例は肝機能検査值の悪化例であり, いずれも肝機能 検查值は試験剂薬投与前よりやや異常傾向があったが, MPA 投与により, さらに増悪したため, 主治医により 薬剤に起因する副作用と判定されたものである。臨床検 查成績に扣いては, 上記 2 例を除き, 試験薬剂㲹起因す ると考えられる臨床的に異常な変動は認められなかった (表4-b・8.9).

以上の副作用扎よび臨床検査成績の結果から判定され た概括安全度の評価においては, “ほぼ安全”が THS 群, MPA 群で各 1 例, “安全性汇問題あり”が THS 群 2 例, MPA 群 1 例, “安全でない”が THS 群 1 例であり, “安全”之評価されたものが THS 群 43 例 $(91.5 \%)$, MPA 群46例 $(95.8 \%)$ と両群之も安全性飞 おいては高い評価を得た（表 4-b).

(6) 診察時の総合改善度

投与後の各評価日に，その時点での注射局所の症状の 総合改善度を投与前と比較した 改善度判定では, THS 群抢よび MPA 群の扮の扔のの有効率（軽度改善以上） が，4週目では67.4\% (29/43) および71.8\% (28/39),

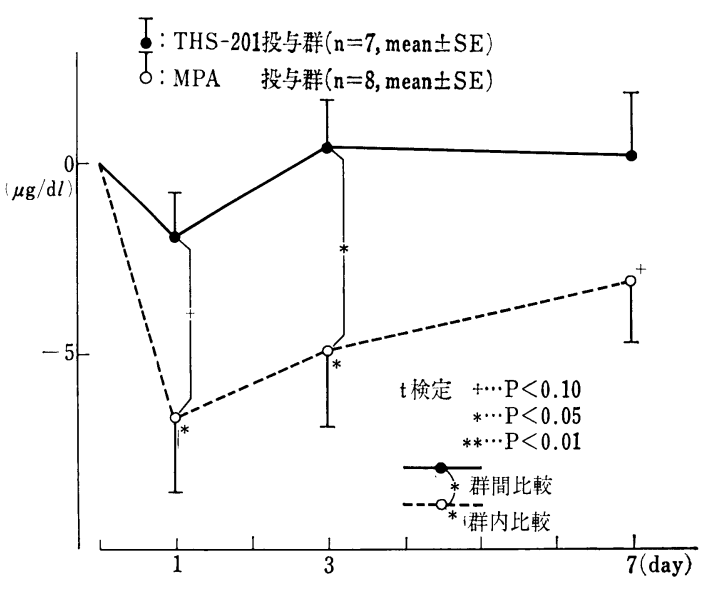

図 3 血清コルチゾール值の変動 （前值との差の平均）

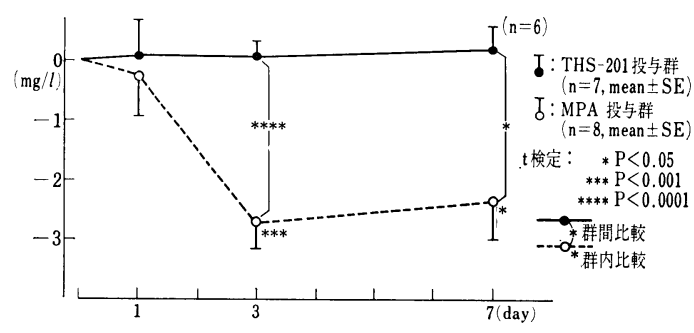

図 4 尿中 17-OHCS 值の変動 （前值との差の平均）

8 週目で $80.0 \%(28 / 35)$ および76.9\%(30/39), 12 週目 で $70.3 \%$ (26/37) および $81.8 \%$ (27/33)，といずれの 評価時期に扎いても両群間に有意差は認められなかった (表6).

（7）全身のリウマチ症状の変動

試験開始時と試験終了時の全身のリウマチ症状の変動 は，それぞれの群内において，試験終了時にTHS 群 で, 朝のこわばりの持続時間, 活動性関節数, 疼痛点数 に有意な改善を認め, MPA 群で, 疼痛点数に有意な改 善, 活動性関節数に改善傾向を認めた。なお, 試験終了 時の両群間の改善程度は, いずれの項目においても有意 差は認められなかった（表 7 ）。

（8）全般有用度

最終総合改善度および概括安全度などを勘案して試験 薬剂の有用性を評価した全般有用度においては, “かな り有用”以上と判定された症例が，THS 群 $61.7 \%$, MPA 群 68.8\%, “やや有用” 以上では THS 群 85.1 $\%$, MPA 群 $85.4 \%$ であり, 両群間には有意差は認め られなかった（表 4-c）。

(9) 全身影響試験

THS および MPA の全身に対するステロイドの作用 をみる目的で実施した全身影響試験は，15例において実 
表 7 症状の推移

\begin{tabular}{|c|c|c|c|c|c|c|c|c|c|}
\hline \multirow{2}{*}{\multicolumn{2}{|c|}{ 評価項目 }} & \multirow{2}{*}{ 薬剂 } & \multicolumn{2}{|r|}{ 試験開始時 } & 検定 & \multicolumn{2}{|r|}{ 試験終了時 } & \multicolumn{2}{|l|}{ 検 } \\
\hline & & & 例数 & 平均値士 S D & 群間 & 例数 & 平均値士 S D & 群間 & 群 内 \\
\hline \multirow{2}{*}{\multicolumn{2}{|c|}{$\begin{array}{l}\text { 朝のこ市ばり } \\
\text { の持続時間(分) }\end{array}$}} & $\mathrm{T}$ & 47 & $62.02 \pm 89.97$ & \multirow{2}{*}{ N S } & 44 & $43.68 \pm 67.17$ & \multirow{2}{*}{ N S } & $*$ \\
\hline & & $M$ & 47 & $83.60 \pm 122.26$ & & 45 & $68.73 \pm 103.22$ & & N S \\
\hline \multirow{4}{*}{$\begin{array}{l}\text { 握兮 } \\
(\mathrm{mmHg})\end{array}$} & \multirow{2}{*}{ 右 } & $\mathrm{T}$ & 45 & $119.47 \pm 71.48$ & \multirow{2}{*}{ N S } & 42 & $112.61 \pm 65.74$ & \multirow{2}{*}{ N S } & N S \\
\hline & & M & 47 & $114.88 \pm 71.83$ & & 41 & $115.54 \pm 67.19$ & & N S \\
\hline & \multirow{2}{*}{ 左 } & $\mathrm{T}$ & 45 & $120.89 \pm 79.55$ & \multirow{2}{*}{ N S } & 42 & $114.21 \pm 75.16$ & \multirow{2}{*}{ N S } & $\mathrm{NS}$ \\
\hline & & M & 47 & $113.93 \pm 77.70$ & & 41 & $109.10 \pm 70.12$ & & $\mathrm{NS}$ \\
\hline \multirow{2}{*}{\multicolumn{2}{|c|}{ Ifll ${ }_{(\mathrm{mm} / \mathrm{hr}}$ 值 }} & $\mathrm{T}$ & 47 & $67.72 \pm 34.19$ & \multirow{2}{*}{ N S } & 43 & $65.47 \pm 33.19$ & \multirow{2}{*}{ N S } & N S \\
\hline & & M & 47 & $70.82 \pm 38.95$ & & 42 & $66.36 \pm 38.39$ & & $\mathrm{NS}$ \\
\hline \multirow{2}{*}{\multicolumn{2}{|c|}{ 活動性関節数 }} & $\mathrm{T}$ & 47 & $9.47 \pm 8.02$ & \multirow{2}{*}{ N S } & 44 & $8.41 \pm 8.20$ & \multirow{2}{*}{ N S } & $*$ \\
\hline & & M & 48 & $9.46 \pm 6.99$ & & 44 & $9.02 \pm 7.73$ & & + \\
\hline \multirow{2}{*}{\multicolumn{2}{|c|}{ 疼 痛 点 数 }} & $\mathrm{T}$ & 44 & $2.02 \pm 0.59$ & \multirow{2}{*}{ N S } & 44 & $1.52 \pm 0.63$ & \multirow{2}{*}{ N S } & $* * * *$ \\
\hline & & M & 47 & $1.96 \pm 0.69$ & & 44 & $1.36 \pm 0.61$ & & $* * * *$ \\
\hline \multirow{2}{*}{\multicolumn{2}{|c|}{$\begin{array}{c}\text { 関 節 液 量 } \\
(\mathrm{m} l)\end{array}$}} & $\mathrm{T}$ & 47 & $9.40 \pm 11.98$ & \multirow{2}{*}{ N S } & 43 & $4.65 \pm 9.01$ & \multirow{2}{*}{ N S } & **** \\
\hline & & $M$ & 48 & $10.81 \pm 16.51$ & & 45 & $2.13 \pm 5.70$ & & ** \\
\hline
\end{tabular}

検定 $\cdot \mathrm{t}$ 検定 NS : not significant

$+: \mathrm{P}<0.10 .{ }^{*} \mathrm{P}:<0.05$. ${ }^{* *} \mathrm{P}:<0.01 . * * *: \mathrm{P}<0.001 . * * * *: \mathrm{P}<0.0001$

施され, 内訳は THS 群 7 例, MPA 群 8 例であった。 図 3,4 に示したごとく, THS 群は投与前値とくらべ, 投与 1 日目， 3 日目，および 7 日目のいずれの評価日に おいても血清コルチゾール值拈よび尿中17-OHCS 值の 有意の変動はみられなかったが, MPA 群では投与 1 日目，3 日目，拉よび 7 日目に血清コルチゾール值の有 意な著明低下が，また，投与 3 日目および 7 日目に尿中 17-OHCS 值の有意な著明低下がそれぞれ認められた。

一方, 血清総蛋白量, 尿中Kについては, 両群とも有 意な変動は示さなかった。 また，尿中 $\mathrm{Na}, \mathrm{Cl}$ に関して は, THS 群では有意な変動はみられなかったが，MPA 群では有意な低下が認められた。

\section{考 察}

慢性関節リウマチ（RA）におけるステロイド関節内 注入療法は，非ステロイド剂などで治療し，なお一ない し数個の関節に頑固な炎症症状がつづく患者を対象に広 く行われている，明らかな効果を示す一方，効果の持続 が短いこと, 局所の副作用あるいは全身性の副作用とい った問題が残されている. 局所貯留性が高く, 全身作用 を示さずなおかつ骨・軟骨にあまり作用しない関注用 の副腎皮質ステロイド剤が開発されれば，注射間隔も延 長され, 関節注入剤としての有用性は高くなるものと考 える。

従来のステロイド関節注入剂は, 懸濁液にもかかわら ず，投与部位から比較的速やかに吸収され，汪とんどが
全身循環に入る ${ }^{2 \sim 3)}$. 内分泌学的検査においても, 関節 内注射後, 血清コルチゾール值の著明な低下が認められ $ろ^{6 \sim 8)}$.

すなわち，ステロイド関節注入剂の臨床効果は, 局所 効果と同時に，全身効果に依存するといった全身投与と かわらない結果を招く懸念がある。実際に広畑らは, 261 名の外来通院患者を対象にして，ステロイド関節注入療 法を行い，他関節に対する効果を調査した 結果，“他関 節にも効果があらわれたものが $26 \%$ もあり，全身が軽く なったと感ずるものが46\%あった”という報告9)をして いる.

日本でステロイド関節注入剤として開発された THS201 (THS) は，動物実験において関節内貯留性がい ちじるしく高く，かつ全身作用を示さないことが認めら れている4,10)。 また, 初期臨床試 験 $^{11)}$, おょび open trial $^{5)}$ でも, 高い有効性と効果の持続性, が認められ, な敃かつ全身作用が認められなかったことが報告されて 扣り，ステロイド関節注入剂として有用性の高い薬剂で あることが認められつつある，そこで今回は，16施設の 共同により，RA を対象にして THS の有用性を確認 する目的で, 酢酸メチルプレドニゾロン (MPA) を対 照薬㓮とする 4 週間隔で 3 回投与し，12週間で効果判定 を行う二重盲検比較試験を実施した。

MPA は，なが年にわたり関節注入剂として頻用さ れ，持続効果，安全性について高く評価されていること から, 対照薬剤として選定し，その投与量は, やや多量 
表 8 副作用症例一覧

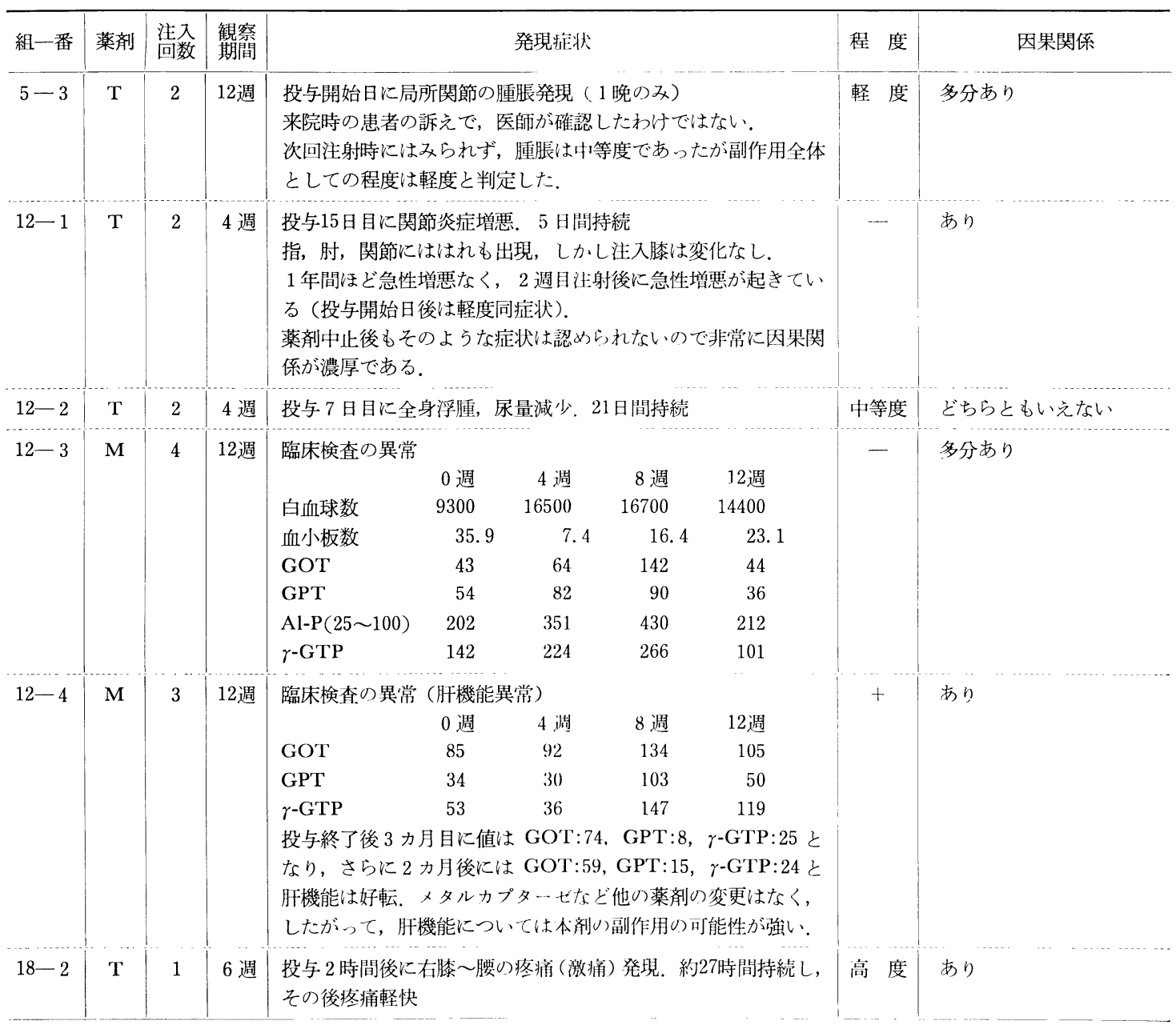

であるが，THS 製剤と外見をそろえるため，成人 RA 患者の膝に対して 1 回 40mg とした。THS 1 回 $25 \mathrm{mg}$ は, 筆者らの報告 ${ }^{5)}$ から, 成人 RA 患者の膝に対して適 当な投与量であろうと考えられ，本試験の用量として採 用した。

患者の背景, 試験薬剂投与開始日の各症状については 問題とすべき差はなく, THS 群と MPA 群の両群は ほぼ同質の患者群で，両群の成績を比較検討するのには 十分に妥当であると考えられた。

成績をみると，最終総合改善度に拈いては，MPA 群 がやや高い有効率を示したが，両群間に差は認められな かった。すなわち，THS 群では “中等度改善” 以上が $59.6 \%$, “軽度改善”以上が $85.1 \%$ の改善率を示したの に対して，MPA 群ではそれぞれ $62.5 \%$, 87.5\%であっ た。

最終総合改善度を裏付ける各評価項目を経時的に久る 之, 自発痛, 圧痛, 他動運動痛, 関節 腫脹, 歩行, 1 : 座，しゃがむ動作，階段昇降のいずれも試験開始後 4 週
日， 8 週目，12週目のいずれの評価時期において両群と も有意な改善を示した。 また，両群間の改善度の比較に おいては, 压痛, 関節腫脹について MPA 群が 12 週目 の観察時において改善を示した。他の項目においては, いずれの評価時期においても両群閒に有意な差は認めら れなかった。

副作用および臨床検査值の変動から判定した概括安全 度は, “安全”が THS 群 91.5\%, MPA 群 $95.8 \%$ で あり，両群間に有意な差は認められなかった。

THS 群に $8.5 \%$ (4/47), MPA 群に $4.2 \%(2 / 48)$ の副作用発現があり, THS 群では局所の腫脹, 局所の 疼痛, 全身の浮腫が各 1 例, また, 被験部位の症状は変 化なく，他関節炎症を増悪させたということで副作用と 判定された症例が 1 例あった。

一方, MPA 群では, 臨床検査上の悪化 2 例（いずれ も肝機能検査值の悪化例) であった。 いずれの副作用 も，試験薬剂の投与中止あるいは投与継続中に消退し， 重篤な副作用は認められなかった。また，臨床検査成績 
表 9 臨床検査成績

\begin{tabular}{|c|c|c|c|c|c|}
\hline 検査項目 & 薬剂 & 例数 & 試験前値 & $\begin{array}{l}\text { 試験後値 } \\
\text { 平均 } \pm \text { SD }\end{array}$ & 結 果 \\
\hline 赤血 球 数 $\left(\times 10^{4} / \mathrm{mm}^{3}\right)$ & $\begin{array}{l}\mathrm{T} \\
\mathrm{M}\end{array}$ & $\begin{array}{l}37 \\
40\end{array}$ & $\begin{array}{l}431.38 \pm 47.74 \\
410.75 \pm 43.22\end{array}$ & $\begin{array}{l}423.57 \pm 51.72 \\
411.25 \pm 53.15\end{array}$ & $\stackrel{+}{\mathrm{NS}}$ \\
\hline 白血球数 $\left(\times 10^{2} / \mathrm{mm}^{3}\right)$ & $\begin{array}{l}\mathrm{T} \\
\mathrm{M}\end{array}$ & $\begin{array}{l}37 \\
40\end{array}$ & $\begin{array}{l}81.35 \pm 19.50 \\
77.25 \pm 22.27\end{array}$ & $\begin{array}{l}80.41 \pm 23.33 \\
80.83 \pm 31.12\end{array}$ & $\begin{array}{l}\text { N S } \\
\text { N S }\end{array}$ \\
\hline 血色 素 量 $(\mathrm{g} / \mathrm{d} l)$ & $\begin{array}{l}\mathrm{T} \\
\mathrm{M}\end{array}$ & $\begin{array}{l}37 \\
40\end{array}$ & $\begin{array}{ll}11.30 \pm & 1.88 \\
10.66 \pm & 1.69\end{array}$ & $\begin{array}{ll}11.09 \pm & 1.76 \\
10.65 \pm & 1.80\end{array}$ & $\begin{array}{l}\text { N S } \\
\text { N S }\end{array}$ \\
\hline 血小板 数 $\left(\times 10^{4} / \mathrm{mm}^{3}\right)$ & $\begin{array}{l}\mathrm{T} \\
\mathrm{M}\end{array}$ & $\begin{array}{l}37 \\
39\end{array}$ & $\begin{array}{l}329.27 \pm 86.93 \\
356.26 \pm 153.75\end{array}$ & $\begin{array}{l}335.81 \pm 118.41 \\
355.31 \pm 121.99\end{array}$ & $\begin{array}{l}\text { N S } \\
\text { N S }\end{array}$ \\
\hline $\mathrm{N}-\mathrm{St}$ & $\begin{array}{l}\mathrm{T} \\
\mathrm{M}\end{array}$ & $\begin{array}{l}27 \\
32\end{array}$ & $\begin{array}{ll}5.48 \pm & 4.08 \\
6.81 \pm & 3.89\end{array}$ & $\begin{array}{l}6.96 \pm 7.10 \\
9.19 \pm \quad 7.78\end{array}$ & $\begin{array}{c}\mathrm{NS} \\
+\end{array}$ \\
\hline N-Seg & $\begin{array}{l}\mathrm{T} \\
\mathrm{M}\end{array}$ & $\begin{array}{l}27 \\
32\end{array}$ & $\begin{array}{l}62.59 \pm 10.85 \\
66.50 \pm 8.13\end{array}$ & $\begin{array}{l}59.89 \pm 11.92 \\
65.63 \pm 10.40\end{array}$ & $\begin{array}{l}\text { N S } \\
\text { N S }\end{array}$ \\
\hline 球 & $\begin{array}{l}\mathrm{T} \\
\mathrm{M}\end{array}$ & $\begin{array}{l}30 \\
35\end{array}$ & $\begin{array}{ll}1.57 \pm & 1.36 \\
2.03 \pm & 2.15\end{array}$ & $\begin{array}{ll}1.33 \pm & 1.52 \\
1.34 \pm & 1.51\end{array}$ & $\begin{array}{c}\mathrm{NS} \\
+\end{array}$ \\
\hline 分 & $\begin{array}{l}\mathrm{T} \\
\mathrm{M}\end{array}$ & $\begin{array}{l}30 \\
35\end{array}$ & $\begin{array}{ll}0.63 \pm & 0.89 \\
0.54 \pm & 0.74\end{array}$ & $\begin{array}{ll}0.73 \pm & 1.11 \\
0.60 \pm & 0.85\end{array}$ & $\begin{array}{l}\text { N S } \\
\text { N S }\end{array}$ \\
\hline$\%$ & $\begin{array}{l}\mathrm{T} \\
\mathrm{M}\end{array}$ & $\begin{array}{l}30 \\
35\end{array}$ & $\begin{array}{l}24.33 \pm \quad 9.76 \\
20.69 \pm \quad 6.98\end{array}$ & $\begin{array}{l}26.20 \pm \\
19.63 \pm \quad 7.39 \\
\end{array}$ & $\begin{array}{l}\text { N S } \\
\text { N S }\end{array}$ \\
\hline M & $\begin{array}{l}\mathrm{T} \\
\mathrm{M}\end{array}$ & $\begin{array}{l}30 \\
35\end{array}$ & $\begin{array}{ll}4.93 \pm & 2.61 \\
4.00 \pm & 2.31\end{array}$ & $\begin{array}{ll}4.63 \pm & 3.13 \\
4.00 \pm & 2.44\end{array}$ & $\begin{array}{l}\text { NS } \\
\text { N S }\end{array}$ \\
\hline GOT (unit) & $\begin{array}{l}\mathrm{T} \\
\mathrm{M}\end{array}$ & $\begin{array}{l}37 \\
40\end{array}$ & $\begin{array}{l}18.14 \pm 12.26 \\
20.15 \pm 13.89\end{array}$ & $\begin{array}{l}20.68 \pm 23.17 \\
24.20 \pm 41.24\end{array}$ & $\begin{array}{l}\text { N S } \\
\text { N S }\end{array}$ \\
\hline GPT (unit) & $\begin{array}{l}\mathrm{T} \\
\mathrm{M}\end{array}$ & $\begin{array}{l}37 \\
39\end{array}$ & $\begin{array}{l}13.73 \pm 17.34 \\
14.23 \pm \quad 9.92\end{array}$ & $\begin{array}{l}15.89 \pm 29.83 \\
21.64 \pm 61.91\end{array}$ & $\begin{array}{l}\text { N S } \\
\text { N S }\end{array}$ \\
\hline BUN $(\mathrm{mg} / \mathrm{d} l)$ & $\begin{array}{l}\mathrm{T} \\
\mathrm{M}\end{array}$ & $\begin{array}{l}37 \\
38\end{array}$ & $\begin{array}{ll}18.75 \pm & 6.20 \\
16.94 \pm & 6.47\end{array}$ & $\begin{array}{l}18.03 \pm \quad 7.14 \\
16.53 \pm \quad 5.71\end{array}$ & $\begin{array}{l}\text { N S } \\
\text { N S }\end{array}$ \\
\hline クレアチニン $(\mathrm{mg} / \mathrm{d} l)$ & $\begin{array}{c}\mathrm{T} \\
\mathrm{M}\end{array}$ & $\begin{array}{l}36 \\
38\end{array}$ & $\begin{array}{ll}0.80 \pm & 0.24 \\
0.74 \pm & 0.25\end{array}$ & $\begin{array}{ll}0.79 \pm & 0.31 \\
0.72 \pm & 0.26\end{array}$ & $\begin{array}{l}\text { N S } \\
\text { N S }\end{array}$ \\
\hline $\mathrm{Na}^{+}(\mathrm{mEq} / \mathrm{l})$ & $\begin{array}{l}\mathrm{T} \\
\mathrm{M}\end{array}$ & $\begin{array}{l}27 \\
27\end{array}$ & $\begin{array}{ll}141.37 \pm & 2.54 \\
141.81 \pm & 2.04\end{array}$ & $\begin{array}{ll}141.74 \pm & 2.14 \\
141.63 \pm & 2.29\end{array}$ & $\begin{array}{l}\text { N S } \\
\text { N S }\end{array}$ \\
\hline $\mathrm{K}^{+}(\mathrm{mEq} / l)$ & $\begin{array}{l}\mathrm{T} \\
\mathrm{M}\end{array}$ & $\begin{array}{l}27 \\
27\end{array}$ & $\begin{array}{ll}43.56 \pm & 3.52 \\
41.67 \pm & 4.21\end{array}$ & $\begin{array}{l}42.07 \pm \quad 3.60 \\
41.48 \pm \quad 3.78\end{array}$ & $\stackrel{+}{\mathrm{NS}}$ \\
\hline $\mathrm{Cl}^{-}(\mathrm{mEq} / l)$ & $\begin{array}{l}\mathrm{T} \\
\mathrm{M}\end{array}$ & $\begin{array}{l}27 \\
27\end{array}$ & $\begin{array}{ll}104.48 \pm & 2.65 \\
105.26 \pm & 2.51\end{array}$ & 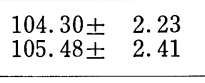 & $\begin{array}{l}\text { N S } \\
\text { N S }\end{array}$ \\
\hline 血 清 総 蛋 白 $(\mathrm{g} / \mathrm{d} l)$ & $\begin{array}{l}\mathrm{T} \\
\mathrm{M}\end{array}$ & $\begin{array}{l}26 \\
27\end{array}$ & $\begin{array}{ll}74.04 \pm & 3.76 \\
75.48 \pm & 5.77\end{array}$ & $\begin{array}{ll}73.96 \pm & 5.13 \\
73.67 \pm & 5.57\end{array}$ & $\underset{*}{\mathrm{~N} \mathrm{~S}}$ \\
\hline 空腹時 血糖 (mg/dl) & $\begin{array}{l}\mathrm{T} \\
\mathrm{M}\end{array}$ & $\begin{array}{l}5 \\
6\end{array}$ & $\begin{array}{r}78.40 \pm 42.99 \\
106.00 \pm 79.47\end{array}$ & $\begin{array}{r}81.80 \pm 44.01 \\
103.50 \pm 62.14\end{array}$ & $\begin{array}{l}\text { N S } \\
\text { N S }\end{array}$ \\
\hline
\end{tabular}

NS: not significant. $+: \mathrm{P}<0.10 . \quad * \mathrm{P}<0.05$

では, 上述の肝機能検査值の悪化例を除き, 臨床的に問 題とすべき変動はみられなかった。すなわち, 各群にお ける試験前・後の平均值の比較で, 有意の変動を示した ものは, MPA 群の血清総蛋白の減少であり, ステロイ ド剂の全身効果と考えられた。

担当医の評価による最終総合改善度, 概括安全度, お よび治療上の必要性などを加味した全般有用度において は, THS 群では“かなり有用”以上が $61.7 \%$, “やや 有用”以上が $85.1 \%$ の有用率を示したのに 対し，MPA 群ではそれぞれ $68.8 \%, 85.4 \%$ であり, 両群間に有意
な差は認められなかった。

つぎに，試験薬剤の 全身影響を二重盲検比較試験 で 検討した. 各群 $7 \sim 8$ 例での検討であるが，THS 群で は血清コルチゾール值, 尿中 17-OHCS 值とも, 投与 前值とくらべ投与後 1 日目， 3 日目，および 7 日目のい ずれの評価項目に特いても臣とんど変動はみられなかっ たが，MPA 群では投与後 1 日目，3日目，および 7 日 目に血清コルチゾール值の有意で，しかも著明な低下 が，また，投与後 3 日目および 7 日目に尿中 17-OHCS 值の有意で著明な低下がみられた。 
今回の成績は, RA のステロイド関節注入剤として, THS $25 \mathrm{mg}$ が, MPA 40mg にくらべ，局所効果と一 般的な副作用発現からみて，同等の有用性を発揮するこ とを示すものである。ささらに，副腎機能の抑制など全身 作用のある MPA にくらべ，全身的影響が検討した範 囲ではまったくない点は特筆すべきである。

すなわち，本剤は RA に対するすぐれたステロイド 関節注入剂と考えられる。

\section{まとめ}

慢性関節リウマチを対象として THS-201 (halopredone acete) の有効性, 安全性, および有用性を本剂 25 $\mathrm{mg}$ (THS) を被験薬剂, 酐酸メチルプレドニゾロン 40 mg (MPA) を対照薬剂とし，4 週間隔 3 回投与による 16施設共同の二重盲検比較試験の結果，以下の成績が得 られた。

(1) 試験に組み入れられた症例 97例 (THS 群49例, MPA 群48例) のらち, 最終総合改善度解析対象例, 概 括安全度解析対象例, 全般有用度解析対象例はいずれも 95例（THS 群47例, MPA 群48例) であり，これらの 解析対象例の背景については両群間に有意の偏りは認め られなかった。

(2) 最終総合改善度は THS 群 “中等度改善” 以上が $59.6 \%$ ，“軽度改善”以上が $85.1 \%$ であり, MPA群では それぞれ $62.5 \%, 87.5 \%$ であった。

概括安全度は THS 群では“安全”が $91.5 \%$, MPA 群では $95.8 \%$ であった。

全般有用度は THS 群“かなり有用”以上が $61.7 \%$, “やや有用”以上が $85.1 \%$ であり，MPA 群はそれぞれ 68.8\%，85.4\%であった. 総合判定に拈いてそれぞれ MPA 群がやや高率であったが，兩群間に有意差は認め られなかった。

(3) 各臨床症状を経時的にとらえた改善度について は，両群とも明らかな改善が認められている．群間比較 では, 12週後の圧痛および関節腫脹に秥いて, MPA 群 が高い改善を示した。

(4) 副作用は THS 群の $8.5 \%(4 / 47)$, MPA 群 の $4.2 \%(2 / 48)$ に発現した. THS 群では局所の浮 腫, 疼痛, 全身の浮腫, 拈よび対象関節以外の関節炎症 増悪という症例であった。一方, MPA 群の 2 例は, い ずれも臨床検査值の悪化（肝機能検査值の悪化）症例で あった。

(5) 全身影響試験による 血清 コルチゾール值, 尿中
17-OHCS 值の投与前值に対する変動は, THS 群では いずれも有意な変動を示さなかった，MPA 群では，両 值とも有意で, しかも著明な低下がみられ，全身的影響 が強いことが認められた。

(6) 以上の結果から, THS は 1 回 $25 \mathrm{mg} 4$ 週間隔投 与により, 慢性関節リウマチの慢性疼痛, 炎症症状の抑 制に従来の強力なステロイド関節注入剂にくらべ，局所 効果は劣らぬ効果を発揮し，な招かつ，全身的影響が認 められない薬剤であることから，臨床上，ステロイド関 節注入剂として有用な薬剤になると考えられる。

\section{文 献}

1) Hollander, J.L. et al.: Hydrocortisone and cortisone injected into arthritic joints. JAMA $147: 1629-1635,1951$.

2) Willson, M. et al.: Rate of disapearance and metabolism of hydrocortisone and cortisone in the synovial cavisy in rheumtoid arthritis. Proc. Soc. Exper. Biol. \& Med. 83: 648-654, 1953.

3) Oka, M.: Absorption of hydrocortisone from the joint cavity into the circulation. Ann. Rheum. 15: 327-329, 1956.

4) Mizushima, Y., Miyake, H., Fujiwara, K., Ono, N., Takikawa, K.: A Highly topically active corticosteroid. Arzneim. Forsch./Drug Res. 30(1): 2: 274-275, 1980.

5）塩川優一・他：慢性関節リウマチに対するTHS201 の臨床試験。（投稿中）

6) Shuster, S.: Adrenal suppression due to intraarticular cortico-steroid therahy. Lancet 2:171172, 1961.

7) Armstrong, R.D.: Serum methylprednisolone levels following intra-articular injection of methyl prednisolone acetate. Ann. Rheum. Dis. 40: 571-574, 1981.

8) Bird, H.A. Ring, E.F.J., Bacon, P.A.: A thermographic and clinical comparison of three intra-articular steroid preparations in rheumatoid arthritis. Ann. Rheum. Dis. $38: 36-39$, 1979.

9）広畑和志, 石川 斉: 4. 関節腔内注射の功罪。 ウマチ 17(6)：591-593，1977.

10）木庭守, 石川斉, 広畑和志・他：ウサギ抗原 惹起型関節炎と Halopredone diacetate の効果. 第 4 回 日本炎症学会, 1983.

11) Mizushima, Y., Hoshi, K.: Intra-articular injection of a highly topical corticosteroid in rheumatoid arthritis. Drugs Exptl. Clin. Res. 7(5): 633-635, 1981. 